\title{
Unia Europejska i jej granice. W poszukiwaniu modelu integracji na europejskich peryferiach
}

\section{Wprowadzenie}

- tudia nad granicami i pograniczami przeszły długą ewolucję począwszy od okresu powojennego. Do lat siedemdziesiątych dwudziestego wieku koncentrowały się one zazwyczaj na linearnie rozumianych granicach, w szczególności ich wytaczaniu, korygowaniu, uznawaniu, etc. Wraz z upadkiem komunizmu akcent przesunięty został na wymiar socjo-przestrzenny, gdzie studiowane są głównie praktyki ludzkie, które tworza $i$ reprezentuja różnice $w$ przestrzeni ${ }^{1}$. Oznaczało to zmianę podejścia do sposobu badania granic, które przestały być bytami naturalnymi (tak w znaczeniu teorii państwa ${ }^{2}$, jak i rozumieniu geografii politycznej, poszukującej naturalnych ograniczeń procesów politycznych w przestrzeni ${ }^{3}$ ), a stały się konstruktami społecznymi, wynikającymi z socjalizacji ${ }^{4}$. Podejście takie wyznaczało sposób analizy tego, jak tworzone i reprezentowane są różnice. Różnice o charakterze politycznym, społecznym, językowym, ekonomicznym, prawnym, etc. Oznaczało to także przesunięcie głównego nurtu zainteresowania badaczy z granic państwowych na inne granice - mikro- i makroregionalne, miejskie, sąsiedzkie ${ }^{5}$.

Kolejnym impulsem dla rozwijania opisanego kierunku badań okazała się być intensyfikacja procesu integracji europejskiej. Z jednej strony stanowił on kontynuację zachodzących zmian poprzez wspieranie różnorodności, w tym także rozumianej terytorialnie, w szczególności na poziomie regionalnym i transgranicznym ${ }^{6}$. Efektem była emancypacja terytorialnych jednostek subnarodowych wraz z renesansem państwowo niedominujących kultur, grup etnicznych i narodowych, języków, etc. oraz proces tworzenia struktur regionalnych przekraczających granice państwowe: euroregionów oraz Europejskich Ugrupowań Współpracy Terytorialnej. Procesy te wzmacniane był między innymi przez liberalizację reżimów granicznych wewnątrz Unii Europejskiej (UE). Z drugiej jednak strony, postępująca integracja europejska (przede wszystkim w wymiarze rozszerzeń o kolejnych członków) spowodowała ponowne zainteresowanie wytyczeniem ostatecznego kształtu przestrzennego oraz funkcjonalno-przestrzennego Europy rozumianej jako UE. Postawiła więc pytanie o terytorialnie zdeterminowany kształt granic zewnętrznych UE oraz sposób ich organizacji (w tym

\footnotetext{
${ }^{1}$ H. van Houtum, The Geopolitics of Borders and Boundaries, „Geopolitics” 2005, vol. 10, s. 672.

${ }^{2}$ V. Kolossov, Theorizing Borders. Border Studies: Changing Perspectives and Theoretical Approaches, ,Geopolitics" 2005, vol. 10, s. 612 .

${ }^{3}$ T. Lundén, On the Boundry. About humans at the end of territory, Södertörns Högskola, Stockholm 2004, s. $28-35$.

${ }^{4}$ J. T. Checkel, Constructivist approaches to European Integration, ARENA Working Paper 2006, nr 6.

${ }^{5}$ H. van Houtum, The Geopolitics of..., s. 674.

${ }^{6}$ E. Brunet-Jailly, Theorizing Borders: An Interdisciplinary Perspective, „Geopolitics” 2005, vol. 10, s. 640.
} 
zarządzania nimi) w relacji do otoczenia zewnętrznego. Pomimo zmiany przedmiotu zainteresowania, dominujące podejście badawcze wydaje się kontynuować tendencje okresu postzimnowojennego, koncentrując się na społecznej konstrukcji tak rozumianych granic. W podejściu tym nie poszukuje się naturalnych i geograficznie rozumianych determinantów europejskości, lecz raczej bada się, jak granice [zewnętrzne UE] sq tworzone z punktu widzenia symboli, znaków, identyfikacji, reprezentacji, artykulacji i historii ${ }^{7}$. W szczególności w odniesieniu do przestrzeni znajdującej się ,po drugiej stronie”. Badacze koncentrują się na społecznej konstrukcji inkluzji i wykluczenia za pomocą instrumentu, jakim jest granica zewnętrzna UE. Sposób jej tworzenia określa nie tylko przynależność (do Unii), ale także reguluje relacje z otoczeniem, które mogą wyrażać się tak w izolacji, jak i współpracy (ta natomiast może mieć charakter asymetryczny lub partnerski).

\section{Rozrost terytorialny Unii Europejskiej}

Trwający od początku lat siedemdziesiątych dwudziestego wieku proces rozszerzania Wspólnot Europejskich osiagnął swoje apogeum (lecz z pewnością nie koniec, szczególnie w obliczu trwających negocjacji z kolejnymi państwami i aspiracji członkowskich następnych) wraz z dwuetapowym wschodnim rozszerzeniem UE w latach 2004 i $2007^{8}$. Oznaczało ono przesunięcie granic zewnętrznych UE daleko na wschód i południe kontynentu ${ }^{9}$ i w konsekwencji wprowadzenie do debaty na temat integracji europejskiej pilnego pytania o jej finalny kształt terytorialny oraz model relacji z otoczeniem ${ }^{10}$. Problem ten stworzył jednocześnie nową perspektywę analizowania istoty UE. Wcześniejsze prace badały zazwyczaj jej prawno-instytucjonalny charakter, podejmując kwestię międzynarodowego lub (sami)państwowego kształtu tego podmiotu. Konfrontowano międzyrządowy i ponadnarodowy model integracji ${ }^{11}$ widząc UE jako organizację międzynarodową lub super państwo in statu nascendi. Szereg prac analizował UE jako aktora stosunków międzynarodowych, starając się w ten sposób określić jej istotę. Badania politologiczne, zajmujące się przykładowo atrybutem suwerenności państwowej wskazywały, iż Unia Europejska wyszła poza granice wspótpracy międzypaństwowej ${ }^{12}$. Większość tych podejść charakteryzowała się jednak spojrzeniem na zachodzące procesy przez pryzmat centrum integracji, w rozumieniu tak terytorialnym (wyznaczonym przez „Brukselę” i ,,brukselskie instytucje”), jak i podmiotowym (rdzeń - oparty na francusko-niemieckim tandemie - tworzony przez grupę najgłębiej zanurzonych w procesach integracyjnych państw).

Ostatnie lata charakteryzują się - obok opisanych podejść - próbami zmiany perspektywy opisu procesów integracyjnych. Spojrzenie na UE przez pryzmat jej peryferii i granic zew-

\footnotetext{
${ }^{7}$ H. van Houtum, The Geopolitics of..., s. 675.

${ }^{8}$ Szarzej na ten temat traktuje: Negocjowanie granic: Od „UE-15” do ,UE-27”. Rozszerzenie Wschodnie Unii Europejskiej. Część pierwsza - „, Grupa Luksemburska” (2004), red. T. Szymczyński, Wydawnictwo Naukowe WNPiD UAM, Poznań 2009; Negocjowanie granic: Od ,,UE-15” do „,UE-27”. Rozszerzenie Wschodnie Unii Europejskiej. Część druga - „Grupa Helsińska” (2004-2007), red. T. Szymczyński, Wydawnictwo Naukowe WNPiD UAM, Poznań 2009.

${ }^{9}$ S. Duke, The Enlarged EU and the CFSP, ,,Reports and Analyses of Cnter for International Relations”2004, nr 5.

${ }^{10}$ M. Comelli, E. Greco, N. Tocci, From Boundary to Borderland: Transforming the Meaning of Borders through the European Neighbourhood Policy, ,European Foreign Affairs Review” 2007, nr 12:2.

${ }^{11}$ E. Berg, P. Ehin, What Kind of Border Regime is in the Making? Towards a Differentiated and Uneven Border Strategy, „Cooperation and Conflict” 2006, vol. 41, nr 1, s. 53.

12 Z. Czachór, Suwerenność, wspótzależność i legitymizacja systemu integracyjnego Unii Europejskiej, „,Rocznik Integracji Europejskiej” 2007, nr 1, s. 40.
} 
nętrznych stwarza nowe możliwości w definiowaniu jej charakteru. Umożliwia, po pierwsze, ocenę czy jej terytorialność definiowana jest w sposób charakterystyczny dla bytów (sami)państwowych, których podmiotowość nierozerwalnie związana jest z przestrzenią. Po drugie pozwala na określenie roli centrów i peryferii, w tym w kreowaniu zachowań wobec otocznia zewnętrznego, w szczególności w stosunku do najbliższych sąsiadów.

\section{Centra, peryferie oraz przepływ idei}

Zdefiniowanie roli peryferii w odniesieniu do centrów w UE wymaga spojrzenia na klasyczny sposób opisu występujących między nimi związków. Jukka Kanerva i Kari Palonen opisując relacje pomiędzy centrami i peryferiami zwracają uwagę na jednokierunkowy przepływ idei. Idee powstają zazwyczaj w centrach jednostek polityczno-terytorialnych i przekazywane są do obszarów peryferyjnych tych struktur. Zwracają oni uwagę na fakt, iż uwarunkowania w centrum zazwyczaj różnią się znacząco od tych, które wyznaczają dynamikę funkcjonowania peryferii. Dlatego też wdrożenie określonej idei na peryferiach napotyka częstokroć na trudności wynikające z niedostosowania do lokalnych warunków. W efekcie pochodzące $z$ centrum rozwiązania są niejednokrotnie modyfikowane na peryferiach: bywają inaczej interpretowane lub otrzymują odmienne znaczenie (Schemat 1). Czasami zmienia się nie tylko rozumienie idei, lecz także sama idea. Kanerva i Palonen wyróżniają trzy możliwe scenariusze: po pierwsze skracanie - polega ono na arbitralnym wyborze jedynie tych elementów idei, które korespondują z lokalnymi uwarunkowaniami; po drugie suplementacja - dodanie elementów, które dostosowują ideę do peryferyjnych okoliczności i czynią ją tym samym aplikowalną; po trzecie imitacja - wdrażanie idei bez zrozumienia oraz częstokroć uzasadnienia $^{13}$.

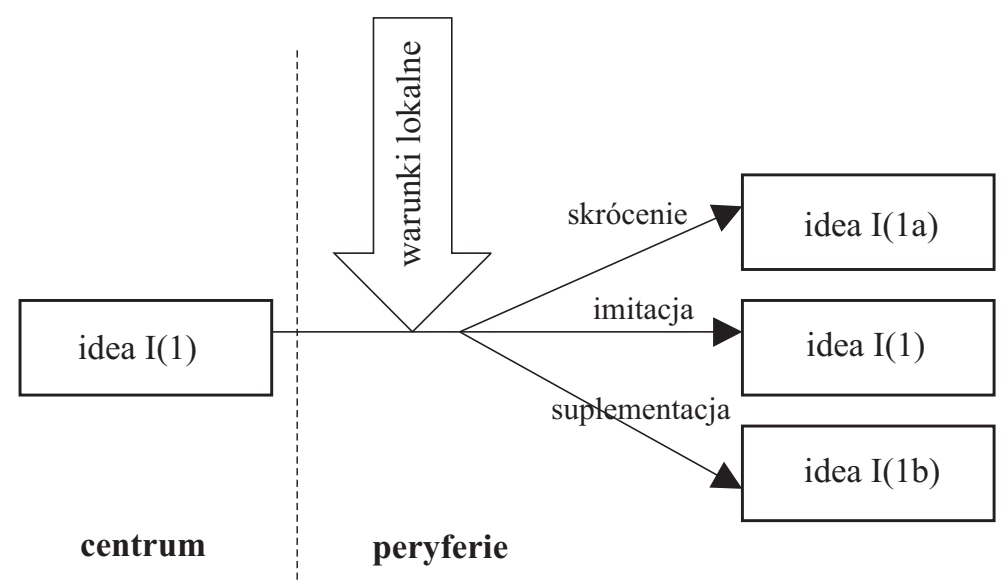

Schemat 1. Przepływ idei z centrum do peryferii

Źródło: Opracowanie własne w oparciu o Transformation of Ideas on a Periphery, red. Kanerva, K. Palonen, The Finnish Political Science Association, Helsinki 1987, s. 9.

${ }^{13}$ Transformation of Ideas on a Periphery, red. Kanerva, K. Palonen, The Finnish Political Science Association, Helsinki 1987, s. 9. 
Opisany model - przyjmując założenia realizmu w analizie stosunków międzynarodowych - nie uwzględnia jednak podmiotowego charakteru peryferii w procesie integracji europejskiej. Pomija więc przynajmniej dwa elementy: Po pierwsze, rolę peryferii w(e) (współ)kreowaniu idei, bazującą na założeniu o podmiotowej roli państw i regionów w procesie integracji. Po drugie, możliwości aktywnej reakcji peryferii na idee pochodzące z centrum, czyli odwróceniu kierunku przepływu idei. Rozwiązanie pochodzące z peryferii może być W sposób efektywny proponowane w centrum, które to musi przynajmniej odnieść się do niego w jeden ze sposobów opisywanych przez przywołanych autorów (Schemat 2). Tutaj elementem określającym dalszy scenariusz są bardzo często potrzeby centrum (koordynującego idee spływające $\mathrm{z}$ różnych peryferii).

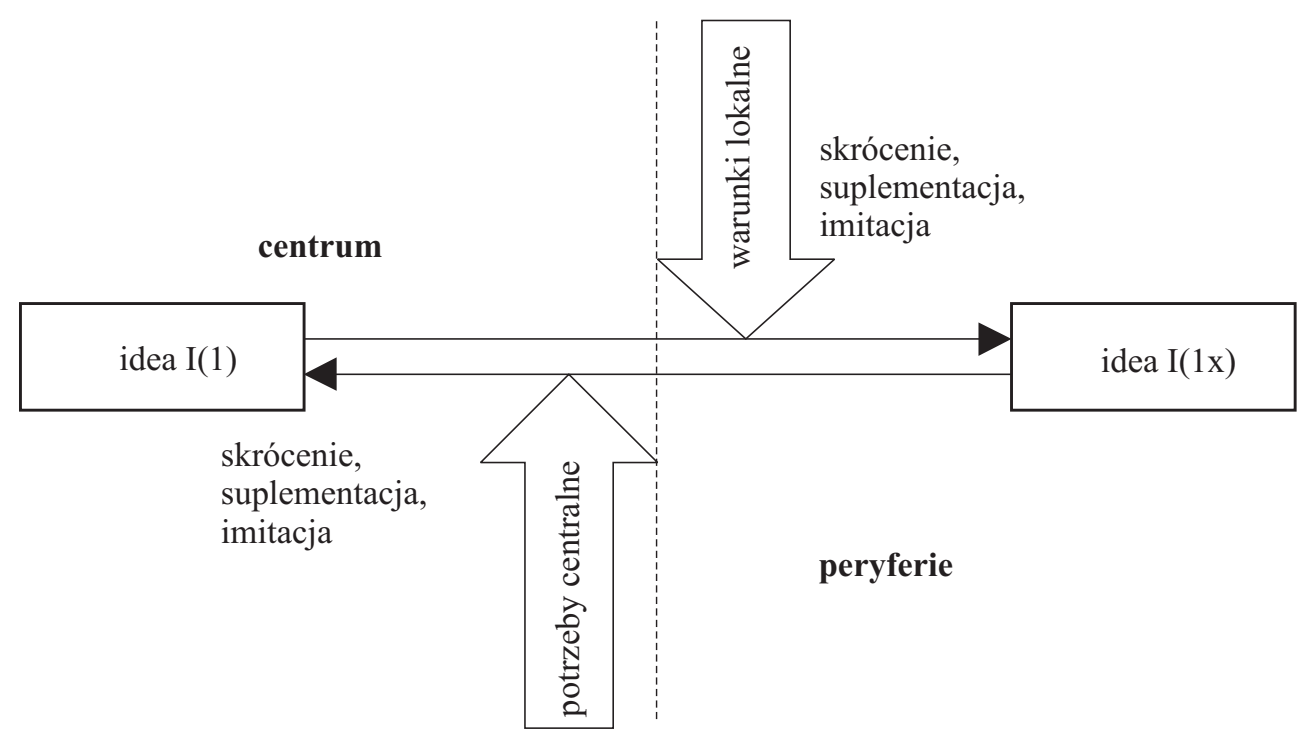

Schemat 2. Dwukierunkowy przepływ idei pomiędzy centrum i peryferiami

Źródło: Opracowanie własne.

Jak pisze Maciej Wilga, zgodnie z pradygmatem konstruktywizmu społecznego integrację należy postrzegać nie tylko jako przestrzeń, w której normy społeczne reguluja wszelkie interakcje między wszystkimi uczestnikami w Unii, ale również jako przestrzeń, w której normy społeczne kraża bez jakichkolwiek ograniczeñ ${ }^{14}$. Normy są więc $\mathrm{w}$ równym stopniu przekazywane z centrum do peryferii, jak i z peryferii do centrum. W procesie definiowania Unii Europejskiej przez pryzmat kształtu i roli granic zewnętrznych, analiza kierunków i sposobów przepływu oraz implementacji idei pomiędzy unijnym centrum (centrami) i peryferiami powinna stanowić skuteczne narzędzie umożliwiające określenie dynamiki strukturalnej UE. Wymaga to określenia ilości (a więc i kształtu) centrów oraz ich pozycji względem peryferii. Dlatego w dalszej części rozważań przedstawiony powyżej schemat zaaplikowany zostanie do modeli geopolitycznych oraz unijnych strategii geopolitycznych.

\footnotetext{
${ }^{14}$ M. Wilga, Integracja europejska w konstruktywizmie, „Przegląd Politologiczny” 2001, nr 1-2, s. 49.
} 


\section{Modele geopolityczne określające relacje centrum-peryferie}

Rozważając istotę UE oraz jej granic Christopher Browning i Pertti Joenniemi przywołują trzy modele geopolityczne rozwoju terytorialno-funkcjonalnego, które mogą stanowić podstawę analizy tej struktury: westfalski, imperialny oraz neośredniowieczny (Schemat 3) ${ }^{15}$.

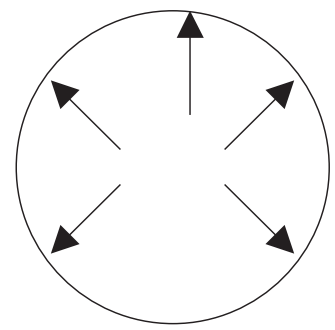

westfalski

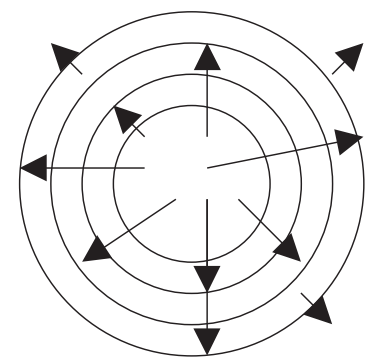

imperialny

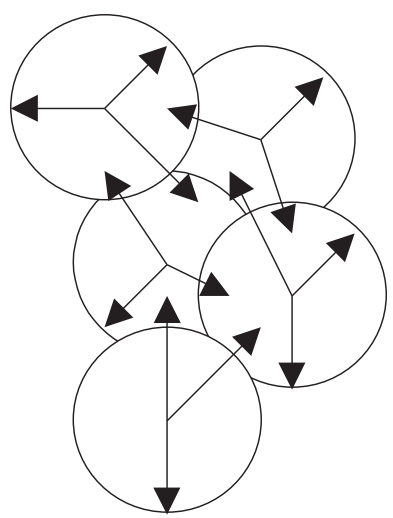

neośredniowieczny

Schemat 3. Modele geopolityczne

Źródło: C. S. Browning, P. Joenniemi, Geostrategies of the European Neighbourhood Policy, „European Journal of International Relations" 2008, vol. 14, nr 3, s. 523.

Model westfalski zakłada logikę rozwoju UE podobną do tworzenia się państw narodowych, z ich jasno zdefiniowanymi granicami zamykającymi określone terytorium. Kontrolowane jest ono przez nowe centrum (Brukselę), która przejmuje kluczowe kompetencje w dziedzinach klasycznie przynależnych państwom narodowym (wspólna waluta, prawodawstwo, wspólna polityka zagraniczna, etc.). Władza sprawowana jest z jednakową siłą i efektywnością na obszarze wszystkich państw członkowskich. Jednolity reżim ochrony granicy w postaci regulacji z Schengen jasno oddziela wnętrze (zorganizowane zgodnie z logiką swobód określonych czterema wolnościami) od otoczenia zewnętrznego, gdzie obowiązują inne regulacje i zasady ${ }^{16}$.

Model imperialny bazuje na centrum i mniej zintegrowanych peryferiach, gdzie wraz z oddalaniem się od środka struktury słabną jej wpływy, co określane jest jako formuła koncentrycznych kręgów ${ }^{17}$. Istnieje wiele granic oznaczających różny stopień zaangażowania $\mathrm{w}$ procesy integracyjne, terytorium jest w znacznej mierze płynne, a jego kształt zależy od określonego obszaru tematycznego integracji. Efektem jest misja rozprzestrzeniania określonych rozwiązań poza kolejne kręgi oddziaływań, a więc eksport norm i standardów europejskich na zewnątrz. Otoczenie zewnętrzne stanowi z jednej strony potencjalne zagrożenie, co powinno wzmagać tendencje do uszczelniania granic, z drugiej eksport stabilności i dobrobytu wymaga granic relatywnie przepuszczalnych. Kreowanie kolejnych koncentrycznych krę-

\footnotetext{
${ }^{15}$ C. S. Browning, P. Joenniemi, Geostrategies of the European Neighbourhood Policy, „European Journal of International Relations" 2008, vol. 14, nr 3, s. 522.

${ }^{16}$ Ibidem.

${ }^{17}$ S. Zyborowicz, Koncepcje integracyjne w eruopejskiej myśli politycznej, „Przegląd Politologiczny” 2004, nr 4, s. 86.
} 
gów ma też konsekwencje dla dalszych rozszerzeń - tworzy ambicje członkowskie i rozmywa jeszcze bardziej granice zewnętrzne Europy ${ }^{18}$.

Model neośredniowieczny zakłada brak jednego centrum, kompetencje ulokowane są w regionach (państwach członkowskich), a decyzje podejmowane w ramach mechanizmów bardziej podobnych do governance niż government. Ważniejsza od terytorium i granic jest tu funkcjonalna sieć powiązań między współdecydującymi ośrodkami ${ }^{19}$.

Klasyczna analiza integracji europejskiej skupiała się na państwopodobnym mechanizmie rozwoju, implikowała więc stosowanie logiki modelu westfalskiego. Jego krytycy wskazywali jednak na dominującą elastyczną formę integracji, czego efektem w wymiarze terytorialnym była koncepcja zmiennej geometrii ${ }^{20}$. Wiele badań wskazuje jednak na inny charakter porządku integracyjnego, co wydaje się być również elementem szerszego porządku w stosunkach międzynarodowych. Jak zauważa Andrzej Gałganek, obecnie wzrastajaca wspótzależność wypłukuje wewnętrznq spójność osiagnięta uprzednio. [...] W rezultacie, współczesny system globalny, w pewnych aspektach, w większym stopniu przypomina Święte Cesarstwo Rzymskie, aniżeli model westfalski ${ }^{21}$. Jak wskazuje Adam Jaskulski, jedną z tez Jana Zielonki jest konieczność odrzucenia przy opisie UE aparatu pojęciowego stosowanego dla badania państwa narodowego i przyjęcie perspektywy porządku neośredniowiecznego, charakteryzującego się takimi elementami jak: nakładające się rzady, podział suwerenności, zróżnicowanie regulacji instytucjonalnych i pluralizm tożsamości $i^{22}$.

Zarówno model westfalski, jak i imperialny przyjmują występowanie jednego, relatywnie homogenicznego centrum. Neośredniowieczny zakłada dla odmiany policentryczność. Peryferia są odbiorcami idei w modelu westfalskim oraz równoprawnymi jej kreatorami w neośredniowiecznym. Model imperialny umożliwia różnoraki stopień recepcji idei przez peryferia i nieuniemożliwia ich tam kreowania. Jednakże sama analiza modeli nadal nie daje pełnego obrazu UE z perspektywy relacji centrum-peryferie. Aby zbliżyć się do niego bardziej, należy zbadać zachowanie Unii w stosunku do sąsiadów na poszczególnych pograniczach - przeanalizować geostrategię UE.

\section{Geostrategie Unii Europejskiej}

William Walters wskazuje na cztery geostrategie stosowane przez Unię Europejską wobec swoich sąsiadów: networked (non)border, march, colonial frontier oraz limes (Schemat 4) ${ }^{23}$.

Networked (non)border - która to nazwa może zostać przethumaczona jako sieciowa (bez)graniczoność - odnosi się przede wszystkim do idei świata bez granic (borderless world $)^{24}$. Zarządzanie samą granicą, jak i różnymi transgranicznymi politykami angażuje wiele centrów decyzyjnych, zarówno po stronie państw członkowskich UE, jak i krajów

\footnotetext{
${ }^{18}$ C. S. Browning, P. Jaenniemi, Geostrategies of the..., s. 524.

${ }^{19}$ Ibidem, s. 524-525.

${ }^{20}$ T. R. Szymczyński, Modelowe założenia zasady elastyczności oraz próba kategoryzacji, w: Unia Europejska po Traktacie Nicejskim, red. Z. Czachór, Biblioteka Europejska UKIE, t. 23, Warszawa 2002.

${ }^{21}$ A. Gałganek, Suwerenna równość państw. Metafora zawłaszczenia, „Przegląd Politologiczny”2007, nr 4, s. 17.

22 A. Jaskulski, Istota i funkcjonowanie Unii Europejskiej w koncepcjach i teoriach integracji europejskiej. Tożsame spojrzenia czy fundamentalne różnice, „Przegląd Politologiczny” 2008, nr 2, s. 70.

${ }^{23}$ W. Walters, The Frontiers of the European Union: A Geostrategic Perspective, „Geopolitics”2004, vol. 9, nr 3.

${ }^{24}$ J. A. Agnew, A World That Knows No Boundaries? The Geopolitics of Globalization and the Myth of a Borderless World, CIBR Working Papers in Border Studies 2003, nr 2.
} 
sąsiedzkich. Stworzona sieć powiązań pozwala na sprawne zarządzanie wszystkimi kwestiami, które przekraczają granice zewnętrzne UE. Jest ono jednocześnie oderwane od terytorium jako takiego, co wydaje się być konsekwencją faktu, iż pojedyncze państwo (tak członkowskie, jak i sąsiedzkie) nie jest zdolne do całkowitego i samodzielnego kontrolowania swojego terytorium i procesów na nim zachodzących. Dotyczy to między innymi takich kwestii jak migracje, bezpieczeństwo wewnętrzne, przestępczość, etc. Dodatkowo granica zewnętrzna, jakkolwiek jasno nakreślona i widoczna, ma również charakter sieciowy: z uwagi na główne sposoby przemieszczania się osób i towarów znajduje się również (a może przede wszystkim) wewnątrz terytoriów - na lotniskach ${ }^{25}$.

March, rozumiany jest jako przestrzeń niczyja, buforowa, oddzielająca terytorium Unii Europejskiej od otoczenia, zmienia on linearną i zdeterytorializowaną percepcję granicy. W tym ujęciu jest ona nie linią, lecz przestrzenią położoną pomiędzy dwoma obszarami. $\mathrm{Z}$ perspektywy unijnej jest to obszar chroniący przed zagrożeniami z zewnątrz (a więc nie zewnętrzny), ale jednocześnie znajdujący się poza strukturami unijnymi (a więc nie wewnętrzny). Mogą tworzyć go całe państwa lub nawet regiony (przykładowo Europa Środkowa przed wschodnim rozszerzeniem, a następnie wdrożeniem regulacji z Schengen $)^{26}$.

Colonial frontier określona może być jako granica kolonialna. Charakteryzuje się ona - podobnie do dziewiętnastowiecznej Ameryki Północnej - występowaniem dwóch obszarów: „ucywilizowanego" i ,do ucywilizowania”. Cywilizacja, poprzez kontakt ze swoim otoczeniem, prowadzi nieustanny eksport norm, wartości, rozwiązań, etc. Powoduje to jej ekspansję i zmienianie obszarów dotychczas nieucywilizowanych, czego efektem jest nowe, silne imperium. Granica ma charakter linii, lecz linii o mobilnym charakterze, której lokalizacja nieustannie zmienia się, powiększając obszar cywilizacji. Granica jest jednocześnie przepuszczalna, ale tylko jednostronnie. W tym rozumieniu geostrategia UE polegałaby na nieustannym poszerzaniu terytorialnym poprzez narzucanie własnych rozwiązań peryferyjnie położonym sąsiadom w procesie ich europeizacji. Ta natomiast powinna prowadzić do członkostwa kolejnych państw oraz powiększania się terytorium i siły $\mathrm{UE}^{27}$.

Limes to ostatnia geostrategia, nawiązująca do dziedzictwa Imperium Rzymskiego. Sam limes to koniec terytorium, ostateczna granica pomiędzy obszarem wysokocywilizowanym i jego otoczeniem. Tutaj jednak - w odróżnieniu od granicy kolonialnej-(względna) trwałość wyznacza przebieg podziału ${ }^{28}$.

Próba oceny relacji z otoczeniem za pomocą jednej tylko z opisanych geostrategii skazana jest na niepowodzenie z uwagi na odmienność stosowanych metod. Browning i Joenniemi proponują więc regionalne zróżnicowanie podejścia do oceny geostrategii UE - a tym samym jej charakteru - w zależności od pogranicza. Twierdzą oni, iż w przypadku sąsiedztwa wschodniego obserwujemy najwięcej cech charakterystycznych dla granicy kolonialnej, a zachowanie UE przypomina (z perspektywy tej granicy zewnętrznej) model imperium. Wschodni sąsiedzi reprezentują odbiorców idei, wschodni członkowie w znaczący sposób prowadzą politykę misji cywilizacyjnej. Obydwie strony zakładają możliwość członkostwa w (bliżej nieokreślonej) przyszłości. Sąsiedztwo południowe reprezentuje dla odmiany geostrategię typu limes, ponownie z imperialnym modelem UE. Południowe państwa sąsiedzkie nie pretendują do członkostwa, nie ma również takiej widocznej koncepcji wśród południo-

\footnotetext{
${ }^{25}$ W. Walters, The Frontiers of the..., s. 679-683.

${ }^{26}$ Ibidem, s. 683-686.

${ }^{27}$ Ibidem, s. 686-690.

${ }^{28}$ Ibidem, s. 690-692.
} 


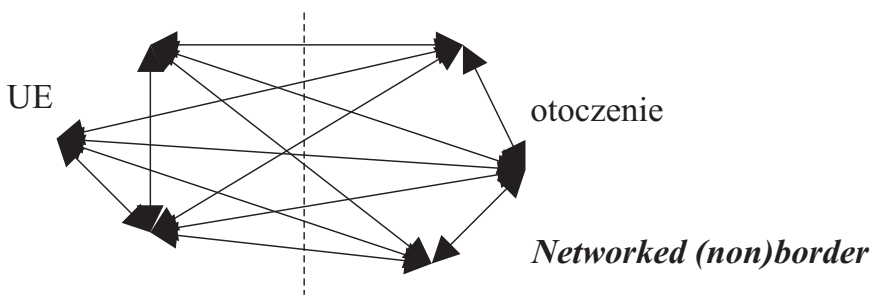

UE

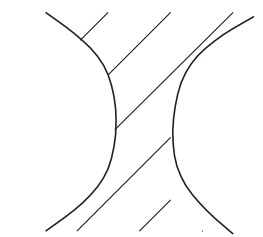

otoczenie

$$
\text { U }
$$

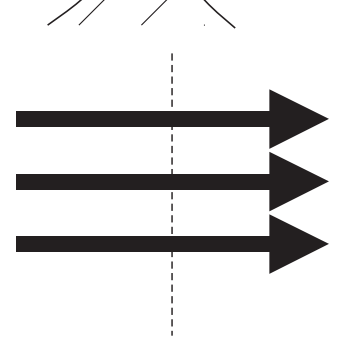

March

UE

otoczenie

\section{Colonial frontier}

UE

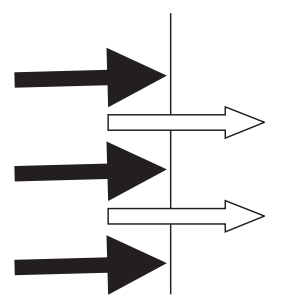

$$
\text { otoczenie }
$$

\section{Limes}

Schemat 4. Geostrategie Unii Europejskiej

Źródło: C. S. Browning, P. Joenniemi, Geostrategies of the European Neighbourhood Policy, ,European Journal of International Relations” 2008, vol. 14, nr 3, s. 528 .

wych członków UE. Pozostają one jednocześnie odbiorcami idei i rozwiązań pochodzących z centrum. Organizacja północnego sąsiedztwa bazuje na geostrategii sieciowej (bez)graniczności, a sama UE jawi się jako organizm neośredniowieczny. Obydwa elementy widoczne były szczególnie mocno przed wschodnim rozszerzeniem w partnerskim nastawieniu, obejmującym partycypację i aktywne uczestnictwo w kreowaniu poszczególnych polityk tak krajów członkowskich, jak i sąsiedzkich ${ }^{29}$.

Przynajmniej dwa podejścia widoczne są w opisanych politykach UE adresowanych do państw stanowiących otoczenie sąsiedzkie. Pierwsze z nich zakłada, iż niektóre państwa sąsiedzkie powinny stać się członkami po wypełnieniu określonych warunków. Ta polityka warunkowości stanowi ucieleśnienie efektywnego eksportu norm i wartości, w wyniku czego

${ }^{29}$ C. S. Browning, P. Joenniemi, Geostrategies of the..., s. 536-544. 
rozszerza się obszar stabilności politycznej i ekonomicznej, i w efekcie powiększa się i wzmacnia sama Unia. Jest to przykład wymiaru wschodniego i geostrategii granicy kolonialnej oraz przedrozszerzeniowego wymiaru wschodniego z sieciową organizacją. Drugie mówi o stabilizacji bez perspektywy członkostwa, a jedynie o szerokim partnerstwie i współpracy. Celem jest nadal stabilizacja w najbliższym sąsiedztwie ${ }^{30}$, co widoczne jest na południu i obecnie na północy.

Kolejną kwestią wymagającą wyjaśnienia jest niewątpliwie rola unijnych peryferii w kreowaniu opisanych geostrategii. Czy są one produktem centrum, czy też efektem peryferyjnych idei, zaakceptowanych w centrum?

Zainteresowanie UE południowymi sąsiadami w basenie Morza Śródziemnego sięga lat siedemdziesiątych dwudziestego wieku. Związane było ono przede wszystkim z zacieśnieniem relacji z Hiszpanią, Grecją i Turcją ${ }^{31}$. Przyjęcie nowych członków w regionie w latach 1981 i 1986 skierowało uwagę Wspólnot dalej na południe, co w latach dziewięćdziesiątych przyjęło formę Procesu Barcelońskiego ${ }^{32}$ i dalej Partnrestwa Środziemnomorskiego ${ }^{33}$. W roku 2008 powołana została do życia Unia na rzecz Regionu Morza Śródziemnego. Był to bezpośredni rezultat inicjatywy francuskiej, zakładającej początkowo udział w niej (oprócz państw sąsiedzkich) jedynie południowych członków UE. Opór Niemiec i innych państw członkowskich rozciągnął inicjatywę na wszystkie 27 państw $^{34}$.

Fiński pomysł wymiaru północnego pojawił się w przemówieniach premiera Paavo Lipponena już w latach 1994 i 1995. Na forum unijnym projekt zaprezentowano w Luxemburgu w grudniu 1997 roku. Rok później w Wiedniu Rada włączyła północny wymiar do stosunków zewnętrznych Unii Europejskiej, prosząc w kolejnym roku o przygotowanie planu $\operatorname{akcji}^{35}$.

Polska przedstawiła propozycje wymiaru wschodniego już w latach 2001 i $2003^{36}$. W roku 2003 minister spraw zagranicznych Włodzimierz Cimoszewicz zaprezentował ideę nowych relacji z krajami poza wschodnią granicą rozszerzonej UE ${ }^{37}$. W 2006 roku Polska i Litwa przedstawiły koncepcję wymiaru wschodniego, który w projekcie Polski i Szwecji przyjął kształt Partnerstwa Wschodniego ${ }^{38}$, zaakceptowanego przez Radę UE w czerwcu 2008 roku $^{39}$.

Regionalnie zróżnicowane geostrategie wydają się być więc przede wszystkim efektem idei pochodzących z peryferii, które dalej zaaprobowano w europejskim centrum. Jak zauważa Beata Piskorska we wszystkich wymienionych wymiarach UE, siła napędowa byty państwa

${ }^{30}$ M. Moschella, European Union 's Regional Approach towards its Neighbors: The European Neighborhood Policy vis-à-vis Euro-Mediterranean Partnership, w: European Neighbourhood Policy: Political, Economic, and Social Issues, red. A. Fulvio, R. Rossi, Jean Monnet Centre, EuroMed, Catania 2004.

${ }^{31}$ E. Bernatowicz, The Barcelona Process as an Instrument of EU Mediterranean Policy, ,Polish Quarterly of International Affairs" 2005, nr 4, s. 17-18.

${ }^{32}$ R. Gomez, The EU's Mediterranean Policy. Common foreign policy by the back door?, w: A Common Foreign Policy for Europe?, red. J. Petersen, H. Sjursen, London 1998, s. 142-146.

33 A. Kołakowska, Partnerstwo Śródziemnomorskie, „Biuletyn PISM” 2003, nr 76 (180).

${ }^{34}$ A. Süel, From the Euro-Mediterranean Partnership to the Union for the Mediterranean, „Perceptions” 2008.

${ }^{35}$ Council Conclusions, Helsinki 10th and 11th December 1999, pkt 62.

${ }^{36}$ The EU's ,Ekstern Dimension”" - An Opportunity fr or Idée FIDE of Poland's Policy?, red. P. Kowal, Centrum Stosunków Międzynarodowych, Warszawa 2002.

${ }^{37}$ B. Przybylska-Maszner, A. Potyrała, Leksykon integracji europejskiej w obszarze Wspólnej Polityki Zagranicznej i Bezpieczeństwa i Europejskiej Polityki Bezpieczeństwa i Obrony, Poznań 2009, s. 258.

${ }^{38}$ M. Lapczyński, The European Union's Eastern Partnership: Chances and Perspectives, ,Caucasian Review of International Affairs" 2009, nr 3, s. 145.

${ }^{39}$ Partnerstwo Wschodnie - raport otwarcia, red. B. Wojna, M. Gniazdowski, Polski Instytut Spraw Międzynarodowych, Warszawa 2009. 
majqce bezpośrednie sqsiedztwo z państwami nieczłonkowskimi, tj. Hiszpania, Francja i Portugalia w odniesieniu do wymiaru śródziemnomorskiego [...], Polska w odniesieniu do wymiaru wschodniego, Finlandia i Szwecja w odniesieniu do wymiaru pótnocnego ${ }^{40}$.

Jednakże idee pochodzące $\mathrm{z}$ peryferii mogą stanowić z perspektywy centrum zagrożenie. W przypadku opisanych wymiarów widoczna stała się też rywalizacja pomiędzy różnymi regionami UE i państwami próbującymi kastomizawać (w rozumieniu Hanny Ojanen - zmieniać ją na kształt pożądany przez dane państwo członkowskie ${ }^{41}$ ) UE. Francuska inicjatywa Unii Śródziemnomorskiej była bezpośrednio spowodowana zbytnią (zdaniem między innymi prezydenta Sarkozy'ego) koncentracją na wschodnim pograniczu w efekcie rozszerzenia z roku 2004 i $2007^{42}$. Autorzy wymiaru wschodniego odwoływali się bezpośrednio do sukcesu wymiaru północnego, widząc w nim receptę na przyciagnięcie uwagi UE wybranego obszaru i kwestii tam dominujących. Efektem była groźba dimensionalizacji Unii. Polegała ona na groźbie jej „rozszarpania” w różnych kierunkach przez rywalizujące ze sobą wymiary terytorialne o sprzecznych geograficznie interesach. Zaproponowaną receptą okazała się być Europejska Polityka Sąsiedztwa, konsolidująca istniejące wymiary oraz zażegnująca niebezpieczeństwo niekontrolowanej deformacji geograficznego środka ciężkości UE. Miała ona zintegrować i skonsolidować akcje UE adresowane do państw sqsiedzkich [...] zabezpieczajac granice UE 'pierścieniem przyjaciót ${ }^{43}$, oferując więcej niż partnerstwo i mniej niż członkostwo ${ }^{44}$. Lokuje to omawiana politykę w obszarze sieciowych powiązań charakterystycznych dla porządku neośredniowiecznego ${ }^{45}$. Jednocześnie jednak pokazuje jak potrzeby centrum - potrzeba konsolidacji struktury - modyfikują peryferyjne idee przetwarzając konkurencyjne projekty w skonsolidowaną, centralnie zarządzaną politykę. Przejawem tego procesu był między innymi fakt, iż istniejące wcześniej instrumenty wparcia finansowego zostały zastąpione przez Europejski Instrument Sąsiedztwa i Partnerstwa, będący częścią Europejskiej Polityki Sąsiedztwa.

\section{Wnioski}

Jak zauważają Browning i Joenniemi, północny wymiar Unii Europejskiej, dzięki naciskowi na tworzenie regionów oraz sieci współpracy, powoduje przebudowanie europejskiej przestrzeni politycznej, promując rozwiązania, które będa korzystne dla obszarów peryferyjnych [...] zmieniajac je w miejsca spotkań, dajace się przekraczać granice oraz obszary kontaktu w miejsce odległych skrajni [...] - w znaczeniu ,europejskich kól olimpijskich” zamiast ,,europejskich kręgów koncentrycznych ${ }^{46}$. Obszary peryferyjne, podobnie do państw sąsiedzkich,

${ }^{40}$ B. Piskorska, Wymiar wschodni Unii Europejskiej-komplementarny czy konkurencyjny dla pozostalych kierunków polityki zagranicznej Unii?, ,Środkowoeuropejskie Studia Polityczne” 2009, nr 1-2, s. 230.

${ }^{41}$ H. Ojanen, How to Customise Your Union. Finland and the Northern Dimension of the EU, „Northern Dimensions Yearbook", The Finnish Institute of International Affairs, Helsinki 1999.

${ }^{42}$ M. Reiterer, From the (French) Mediterranean Union to the (European) Narcelona Process: The 'Union for the Mediterranean' as Part of the European Neighbourhood Policy, „European Foreign Affairs Review”2009, nr 14, s. 320.

43 A. Cinciara, 'Eastern Partnership'-opening a new chaper of Polish Eastern policy and the European Neighbourhood Policy, „Analyses and Opinions of the Institute of Public Affarirs” 2008, nr 4, s. 5.

${ }^{44}$ L. Delcour, E. Tulmets, Pioneer Europe? The ENP as a Test Case for EU's Foreign Policy, „European Foreign Affairs Review" 2009, nr 14, s. 501.

45 J. Zielonka, Europe as Empire. The Nature of the Enlarged European Union, Oxford University Press, Oxford 2007.

${ }^{46}$ C. Browning, P. Joenniemi, The European Union's Two Dimensions: The Eastern and the Northern, ,Security Dialogue" 2003, nr 4, s. 475-476. 
stają się partnerami i współkreatorami polityk, zamiast ich odbiorcami. Wymiar wschodni dla odmiany przyjmuje inną wizję. Sąsiedzi mają być elementem koncentrycznego porządku, w mniejszym stopniu grając rolę partnerów, w większym podmiotów do „ucywilizowania"47. W odróżnieniu od wschodnich państw członkowskich UE, zachodnie nie widzą partnerstwa wschodniego, jako drogi do członkostwa dla państw sąsiedzkich ${ }^{48}$. W przypadku państw Afryki Północnej i Bliskiego Wschodu wydaje się, iż docelowym modelem współpracy pozostanie stworzenie jedynie strefy wolnego handlu za pomocą umów dwu- i wielostronnych ${ }^{49}$ popartych współpracą w innych dziedzinach. Wymiar północny łączy elementy polityki wewnętrznej i zewnętrznej, pozostałe dwa mają charakter zewnętrzny ${ }^{50}$.

Z przedstawionych rozważań wynika, iż przy analizie istoty UE z perspektywy jej peryferii dwukierunkowy przepływ idei wydaje się być modelem dominującym. Peryferyjne inicjatywy regulacji relacji z otoczeniem są akceptowane w centrum, które jednocześnie modyfikuje ich kształt i formę przez pryzmat własnych potrzeb. Efektem są regionalnie zróżnicowane strategie, pokazujące tak policentryczność UE, jak i jej monocentryczny charakter oraz różny typ geostrategii granicznych na każdym z trzech pograniczy.

\section{Summary}

Research into borders and frontiers in the context of European integration has evolved, leading to the question of the shape of the external borders of the EU and their organization in relation to the external surroundings. The approach to how the unification processes of the continent are presented has recently changed, and the Union is being perceived through its peripheries. The one-way model of the flow of ideas from the center to the peripheries has been replaced by a two-way one. This allows us to use the Westfalen, imperial and neo-medieval geopolitical model to analyze the EU and, consequently, the four geo-strategies that are regionally diversified in the northern, eastern and southern peripheries of the Union. Nevertheless, it is the periphery that plays the key role and initiates certain types of relations with neighbors, whereas the center approves of them and modifies them, according to its own requirements.

${ }^{47}$ C. Browning, P. Joenniemi, The European Union's..., s. 476.

${ }^{48}$ D. Milczarek, Eastern Dimension of the European Union's Foreign Policy, ,Y Yearbook of Polish European Studies" 2006, nr 10, s. 13.

${ }^{49}$ M. Benedek, From Neighbour to Member of Associate? The Future of the European Union's Neighbourhood Policy, „EU Policy Network”, October 2003, s. 10.

${ }^{50}$ B. Piskorska, Wymiar wschodni Unii Europejskiej-komplementarny czy konkurencyjny dla pozostatych kierunków polityki zagranicznej Unii?, ,Środkowoeuropejskie Studia Polityczne” 2009, nr 1-2, s. 231. 
